\title{
Knowledge and attitude toward ethics committee and ethical research practice among researchers of three sectors: An institutional study in Kuwait
}

Rashmi Shiju ( $\nabla$ rashmi.shiju@dasmaninstitute.org )

Dasman Diabetes Institute

Smitha Thankachan

Dasman Diabetes Institute

Ayesha Akhil

Dasman Diabetes Institute

Prem Sharma

Dasman Diabetes Institute

Abdullah Bennakhi

Dasman Diabetes Institute

\section{Research Article}

Keywords: Ethics committee, Ethical principles, Informed consent, Misconduct, Knowledge, Awareness

Posted Date: June 16th, 2021

DOI: https://doi.org/10.21203/rs.3.rs-596066/v1

License: (c) (i) This work is licensed under a Creative Commons Attribution 4.0 International License. Read Full License 


\section{Abstract \\ Background}

Adherence to ethical guidelines in the conduct of research is of paramount importance. This ensures that the research is conducted with integrity which in turn builds trust in the researchers and their results. However, misconduct occurs frequently in the research.

\section{Methods}

In this anonymous online cross-sectional survey, researchers from Dasman Diabetes institute were surveyed about their knowledge of and attitude toward ethics committee and research ethics practices across sectors. The study was conducted in November and December 2019 using an online Microsoft forms questionnaire. The questionnaire was divided into five parts including demographics, knowledge of ethical principles and the function of ethics committee, knowledge of ethics and attitudes toward ethics committees and ethical practices. Question-formats were combination of multiple-choice, yes or no, and five-point Likert-scale formats. Researchers applied, the Chi-square test, the KolmogorovSmirnov test, ANOVA, the nonparametric Kruskal-Wallis test, the Student's t-test, and or the Mann-Whitney U test for data analysis.

\section{Results}

The study had a response rate of $86 \%$. Among the 55 participants of this study, 43 (78\%) had prior training in research ethics. Those with maximum training were from the medical sector $(82.4 \%)$ followed by the research sector $(80.8 \%)$ and operations sector (66.7\%). Significant association was observed between prior ethics training and different number of projects handled by a respondent. Similar significant association was noted among the trained participants on knowledge and awareness of the role of the ethics committee, ethical principles, the committee's ways of reviewing protocol and attitude towards consenting process. However, knowledge and awareness of ethics committee and its function varied significantly across sectors and across different number of projects handled. Attitude toward ethical practices such as misconduct and manipulation of data was also found to vary significantly across sectors.

\section{Conclusion}

Our study demonstrated that research sector and medical sector were aware of the knowledge and attitude toward ethics committee, its function and research ethical practices in comparison to operations sector. This indicates a gap in knowledge and attitude which can be bridged by continuous and customized ethics training based on the type of research.

\section{Background}

The word ethics has its roots in the Greek "word ethos" meaning morality. Moral values are a subjective preference, whereas ethics suggest a responsible action of the individual or a group in a situation [1, 2].

Research ethics involves applying the moral values and professional codes of conduct during the entire research process of data collection, analysis, reporting, and dissemination of information through publication [3]. Fundamental ethical principles and guidelines have been established for the responsible conduct of research. These guidelines are applied at all stages of research. The present biomedical research ethics guidelines emerged partly because of various research scandals and infamous experiments conducted in the past. The guidelines evolved from the Nuremberg code in 1947, the Declaration of Helsinki in 1964, the Belmont report in 1979, the Council for International Organization of Medical Science in 
1963 and the International Conference for Harmonization Good Clinical Practice in 1996 [4-7]. Following these guidelines ensures that the research outcome is authentic and free of error and plagiarism and that scientists gain credibility and support from the scientific community. Besides these guidelines, institutional review boards or ethics committees regulate research on human subjects $[8,9]$.

Ethics committees have a significant task in guaranteeing the moral principles and scientific merit of research including the safety of human participants by reviewing research protocols on the basis of three cardinal principles of ethics,: respect for persons, beneficence, and justice [10]. There are three important obligations placed on the ethics committee. First and foremost, the ethics committee should guarantee that the rights of research participants are ensured. This is accomplished by ensuring that participants effectively perceive the given information and guaranteeing that appropriate approaches are set up to safeguard participants from unfavorable results of the participation. Second, the ethics committee has a commitment to the society that delivers the resources to research and that will eventually be affected by the research outcomes. Third, the ethics committee has a commitment to the scientist. The research proposal must be treated with thoughtful deference. All researchers should welcome the commitment made by the ethics committee toward the research process because the committee helps guarantee that the research meets the high ethical and scientific standards [11].

Active monitoring of all research activities is mandatory to safeguard research participants from being exploited in the name of science. All research built on human participation needs pertinent approval from the ethics committee before the initiation of research [12].

Research falsification, fraud, fabrication, ignorance, and deception of research can have far-reaching effects on the health and safety of human participants. A shocking unethical incident was perpetrated by a scientist who "created" the first gene-edited babies, designed to be naturally immune to the human immunodeficiency virus. In the wake of this incident, the Chinese government took serious action by drafting new regulations that would require national approval for research involving gene editing or high-risk biomedical research [13]. Such mindboggling experiments constantly remind us of the importance of complying with ethics awareness. Other unethical research practices are from the fabrication or deception of research data leading to false results. Incidences of data fraud in clinical trials have been reported several times and highlight the importance of routine monitoring of data quality [14]. In another recent scandal of research fraud and misconduct, some serious concerns regarding the scientific integrity of today's publication system have been observed. The number of published non-peer reviewed papers on corona virus diseases 2019 is massive and remains steadily growing [15]. At times, research is conducted unethically, and an increasing number of articles were withdrawn mainly because of misconduct. A cross-sectional survey from a Middle Eastern university has demonstrated the correlation between the lack of ethical awareness and significant research misconduct [16]. This research misconduct is certainly not the first of its kind and is unlikely to be the last. Ensuring data integrity is a professional and ethical obligation.

An authorized ethics committee of any institution should explicitly stipulate the importance of ethics superseding science. Better research outcomes can be reported by strengthening the role of the ethics committee; to include constant, periodic reporting of study progress, and an internal and external auditing system to track ethical adherence [17]. Furthermore, ethical norms dictate that researchers are accountable for their actions and protect their intellectual property and preconceived ideas from being copied or published. If researchers' lack awareness of the ethical guidelines especially when adopting research protocols, it results in poor quality of research, and harm to participants and the reputation of the institute.

Dasman Diabetes Institute (DDI) in Kuwait is a dynamic research institute that focuses on diabetes, and its related complications and management. The institute's researchers are highly experienced and dedicated to bringing about a change in the field of diabetes knowledge and treatment. Currently, the institute undertakes research projects from different specialties: clinical trials, epidemiology, genetics, immunology, molecular biochemistry, health information technology, and 
animal studies. All institutional research activities first go through scientific board review and then, the institution's ethics committee reviews the study protocol for ethical adherence, and informed consent form information, thereby protecting the welfare and rights of participants. The ethics committee at DDI is responsible for ensuring compliance with national and international regulatory standards for the conduct of research on human participants. National regulatory standards include the laws of the State of Kuwait, rules, and regulations of the Ministry of Health, and DDI's policies and guidelines.

A few publications on ethics have been reported from Middle Eastern countries. To the best of our knowledge there are no published data assessing the knowledge and attitude toward ethical principles among researchers in Kuwait. In response to the need for more clarity, the emphasis of this research was to conduct a survey to assess the knowledge, attitude, and awareness of ethical principles among researchers at DDI. The outcome will be an eyeopener, as we know the quality of research findings and their application depend heavily on ethical conduct of research and the ethical perception of researchers.

\section{Method}

Study Design: An anonymous online cross-sectional survey was conducted during November and December 2019 at DDI, Kuwait.

Study Participants: An invitation email was sent to all the participants from the three sectors of the institute: research, medical and operations. The survey included researchers from various backgrounds, qualifications, and positions. The research sector comprised research assistants, research coordinators, scientists and senior scientists. The medical sector comprised nurses and physicians and the operations sector comprised health informatics personnel.

Study Tool: The framing of the questionnaire was adapted from previous studies [18-20]. It was divided into five parts, each having a set of 5-13 questions.

The first part included demographics and general characteristics of the respondents including questions on age, gender, years of experience in research, ethics training underwent, and the number of research projects.

The second part was on research ethics principles and knowledge of the functioning of the ethics committee. This section contained questions to ascertain respondents' knowledge regarding the ethics committee and its functioning. Diverse question formats were used; including multiple-choice questions, dichotomous questions, and five-point Likert-scale questions.

The third part was on knowledge of ethics. Questions were drafted along with scenarios of case studies to gauge respondents' knowledge. Case scenarios tested the knowledge levels of protocol amendment procedures, informed consent and assent form importance and procedures, vulnerable populations, and the safety of research subjects.

The fourth part assessed the respondents' attitude toward the ethics committee using a five-point Likert-scale (1, strongly agree; 2 , agree; 3 , neutral; 4 , disagree; and 5 , strongly disagree).

The fifth part assessed the attitudes toward feedback received from the ethics committee. It had yes, no, and neutral options as choices.

\section{Ethical approval}

This study was approved by DDI's ethical committee. The study protocol was assigned number RA HM-2019-029.

Implied Consent: The online survey was completely voluntary. Completing the questionnaire was considered implied consent. No identifying information regarding the participants was collected. 
Researchers conducted the data management, analysis and graphical presentation using the computer software 'Statistical Package for Social Sciences, SPSS version 25.0 (IBM Corp, Armonk, NY, USA). The data from online questionnaire responses were first transferred to Microsoft Excel, and then converted to SPSS software for statistical analysis. The descriptive statistics have been presented as numbers and percentages for categorical variables, e.g., gender, ethical training attended and work sectors. The quantitative continuous variables; (age, years of experience, and involvement in the number of projects) were first ascertained for normal distribution assumption, applying the KolmogorovSmirnov test, presented as; mean \pm standard deviation or, if skewed, as median and interquartile or range. Researchers applied a chi-square test or Fisher exact test to find any association or significant difference between categorical variables and presented results as percentages of, "yes" or the "correct" or "positive" responses only. Similarly, the responses to questions in the Likert scale, "strongly agree" and "agree" were combined and presented as percent positive responses. Additionally, all the "yes" or "positive/correct" responses were aggregated to find the overall percent response for each subset of the questionnaire. The involvement in the number of research projects was in three categories: "none", " 1 to 3 ", and " 4 or more" projects. The mean values of continuous variables, and overall mean percent responses for each subset were compared among the three work sectors as well as the three groups of research projects involved, by applying ANOVA or nonparametric Kruskal- Wallis tests. The overall mean percent ethical training attended or not, with respect to different subsets, was compared using a Student t-test or a Mann-Whitney U test. The two-tailed probability value "p" of $<0.05$ was considered statistically significant.

\section{Results}

In this online cross-sectional survey, a total of 55 participants gave their implied consent to participate in the survey with a self-reported response rate of almost $86 \%$ (55/64). Respondents were included from the three sectors: research, medical and operations. The questionnaire had 44 questions that were divided into five groups (Supplementary additional file no.1Questionnaire).

Demographics: Table 1 shows the results of the demographic characteristics such as age, gender, overall years of experience, institutional experience, number of projects involved, and ethics training attended among respondents from the three sectors. Overall, of the respondents, $54.5 \%$ were males and $45.5 \%$ were females. The research sector had the highest proportion of male respondents (61.5\%) followed by the operations sector (58.3\%), whereas the medical sector had a higher proportion of female $(58.8 \%)$ respondents. The mean age of the respondents was $42.8 y e a r s( \pm 10.0 S D)$. The mean total years of research experience was 16.8 years $( \pm 9.1 \mathrm{SD})$ and the years of experience at DDI was $6.4 y e a r s( \pm 3.8 S D)$. No significant differences were observed among the respondents from the three sectors in terms of gender, age, or years of experience either total or at DDI ( $p>0.05)$. On average, the respondents were involved in two projects, with an interquartile of (1-4) projects. The maximum involvement in research projects was from the research sector with an average of four projects followed by the medical sector with two projects and then the operations sector with one project. A significant difference was noticed among the three sectors $(p<0.001)$ with respect to number of projects handled. The number of projects handled by the respondents from the research sector was significantly higher than those from the medical sector $(p=0.003)$ or from the operations sector $(p=0.001) .78 .2 \%$ of respondents attended training on ethics, the most being from the medical sector (82.4\%) followed by those from the research sector (80.8\%) and those from the operations sector $(66.7 \%)$. Statistically, no significant difference $(p=0.547)$ was found among the respondents from the three sectors who attended the training.

Table 1: Sector-wise demographics and general characteristics of the respondents 


\begin{tabular}{|c|c|c|c|c|c|}
\hline \multirow[t]{2}{*}{ Sector \& Characteristics } & $\begin{array}{l}\text { All Sectors } \\
\qquad(\mathrm{N}=55)\end{array}$ & $\begin{array}{l}\text { Research } \\
(n=26)\end{array}$ & $\begin{array}{l}\text { Medical } \\
(n=17)\end{array}$ & $\begin{array}{l}\text { Operations } \\
(n=12)\end{array}$ & \multirow[t]{2}{*}{ p-value } \\
\hline & $\mathrm{n}(\%)$ & n (\%) & $\mathrm{n}(\%)$ & $\mathrm{n}(\%)$ & \\
\hline \multicolumn{6}{|l|}{ Gender } \\
\hline Male & $30(54.5)$ & $16(61.5)$ & $7(41.2)$ & $7(58.3)$ & \multirow[t]{2}{*}{0.405} \\
\hline Female & $25(45.5)$ & $10(38.5)$ & $10(58.8)$ & $5(41.7)$ & \\
\hline \multicolumn{6}{|l|}{ Age (years) } \\
\hline$<40$ & $24(43.6)$ & $11(42.3)$ & $6(35.3)$ & $7(58.3)$ & \multirow[t]{2}{*}{0.460} \\
\hline$\geq 40$ & $31(56.4)$ & 15 (57.7) & $11(64.7)$ & $5(41.7)$ & \\
\hline Mean \pm SD & $42.8 \pm 10.0$ & $43.4 \pm 10.8$ & $43.2 \pm 9.3$ & $40.8 \pm 9.8$ & \multirow[t]{2}{*}{0.757} \\
\hline Median (IQ) & $41(36-51)$ & $42(36-51)$ & $41(38-50)$ & $38(32-52)$ & \\
\hline \multicolumn{6}{|l|}{ Years of Experience } \\
\hline Mean \pm SD & $16.8 \pm 9.1$ & $16.4 \pm 10.7$ & $17.6 \pm 7.0$ & $16.5 \pm 8.8$ & \multirow[t]{2}{*}{0.820} \\
\hline Median (IQ) & $15(10-22)$ & $15(8.5-23)$ & $16(12.5-23)$ & 15.5 (8.5-24) & \\
\hline \multicolumn{6}{|l|}{ Experience at DDI (yrs) } \\
\hline Mean \pm SD & $6.4 \pm 3.8$ & $6.7 \pm 3.6$ & $7.0 \pm 2.9$ & $5.0 \pm 5.2$ & \multirow[t]{2}{*}{0.513} \\
\hline Median (IQ) & $7(3-9)$ & $8.5(4-9)$ & $7(5.5-8.0)$ & $3(1-11)$ & \\
\hline \multicolumn{6}{|l|}{ Projects handled } \\
\hline Mean \pm SD & $2.69 \pm 3.24$ & $3.9 \pm 2.2$ & $2.1 \pm 1.6$ & $0.8 \pm 1.5$ & \multirow[t]{2}{*}{$<0.001^{*}$} \\
\hline Median (IQ) & $2(1-4)$ & $4(3-5)$ & $2(1-3)$ & $0(0-1)$ & \\
\hline \multicolumn{6}{|l|}{ \% Ethics training attended } \\
\hline & $43(78.2)$ & $21(80.8)$ & $14(82.4)$ & $8(66.7)$ & 0.547 \\
\hline
\end{tabular}

*Kruskal Wallis test., Mann-Whitney: Res Vs Med $(p=0.003)$ \& Res Vs Op $(p<0.001)$

\section{Training on Research Ethics}

Of the total 55 respondents, $43(78.2 \%)$ had prior ethics training. Table 2 presents the general characteristics of respondents with respect to training. The mean age of those who have attended training was significantly lower than that of those who did not attend ethics training (41.2 vs 48.5 years; $p=0.024)$. Significant association was found between prior ethics training and number of projects handled $(p=0.043)$. Figure 1 presents the association between the ethics training and the number of projects handled.

Table 2: General characteristics of the respondents with respect to training 


\begin{tabular}{|c|c|c|c|c|}
\hline $\begin{array}{l}\text { General } \\
\text { Characteristics }\end{array}$ & $\begin{array}{l}\text { All Respondents } \\
(\mathrm{N}=55)\end{array}$ & $\begin{array}{l}\text { Training attended } \\
(\mathrm{N}=43)\end{array}$ & $\begin{array}{l}\text { Training not attended } \\
(\mathrm{N}=12)\end{array}$ & p-value* \\
\hline \multicolumn{5}{|l|}{ Gender } \\
\hline Male & $30(54.5)$ & $23(53.5)$ & $7(41.2)$ & \multirow[t]{2}{*}{0.766} \\
\hline Female & $25(45.5)$ & $20(46.5)$ & $5(58.8)$ & \\
\hline \multicolumn{5}{|l|}{ Age (years) } \\
\hline Mean \pm SD & $42.8 \pm 10.0$ & $41.2 \pm 8.9$ & $48.5 \pm 12.2$ & 0.024 \\
\hline \multicolumn{5}{|c|}{ Years of Experience } \\
\hline Mean \pm SD & $16.8 \pm 9.1$ & $16.0 \pm 8.0$ & $19.6 \pm 12.2$ & 0.229 \\
\hline \multicolumn{5}{|c|}{ Experience at DDI (yrs) } \\
\hline Mean \pm SD & $6.4 \pm 3.8$ & $6.5 \pm 3.6$ & $6.1 \pm 4.6$ & \multirow[t]{2}{*}{0.984} \\
\hline Median (IQ) & $7(3-9)$ & $8(4-9)$ & $7(1-10)$ & \\
\hline \multicolumn{5}{|l|}{ Projects handled } \\
\hline None & $10(18.2)$ & $5(11.6)$ & $5(41.7)$ & \multirow{3}{*}{0.043} \\
\hline $1-3$ & $26(47.3)$ & $23(53.5)$ & $3(25.0)$ & \\
\hline$\geq 4$ & 19 (34.5) & $15(34.9)$ & $4(33.3)$ & \\
\hline
\end{tabular}

*General Characteristics Vs Training: Chi-square or t-test or Mann-Whitney U test

\section{Knowledge and Attitude toward ethics committee and research ethical practices}

Table 3 shows the knowledge and attitude toward ethics committee and research ethical practices among researchers across the three sectors. The knowledge and awareness of toward the ethics committee and its function among the respondents from the three sectors varied significantly $(p=0.002)$. A marginally significant difference $(p=0.050)$ was also observed in the attitude toward research ethical practices across the three sectors. As shown in Table 4, a positive trend on knowledge and attitude toward ethics committee and research ethical practices was noticed among the respondents who are involved in a higher number of projects (none, 1-3 and $\leq 4$ ).

Table 3. Knowledge and attitude towards ethics committee and research ethical practices across sector respondents (\% 'positive' responses)

*Kruskal-Wallis test among work-areas, \$ Number of questions on the aspect

Table 4 Knowledge and attitude towards ethics committee and research ethical practices according to number of projects handled (\% 'positive' responses)

*Kruskal-Wallis test among respondents involved in number of projects

$\$$ Number of questions on the aspect

Knowledge and awareness of ethics committee and its functions: Table 5 indicates that the overall statistical outcome did not show any major significant association among the trained and untrained respondents. However, few questions on 


\begin{tabular}{|c|c|c|c|c|c|}
\hline Knowledge \& Attitude & $\begin{array}{l}\text { All } \\
\text { Mean } \pm S D \\
\text { (Range) } \\
(n=55)\end{array}$ & $\begin{array}{l}\text { Research } \\
\text { Mean } \pm \\
S D \\
\text { (Range) } \\
(n=26)\end{array}$ & $\begin{array}{l}\text { Medical } \\
\text { Mean } \pm \\
S D \\
\text { (Range) } \\
(n=17)\end{array}$ & $\begin{array}{l}\text { Operations Mean } \\
\pm S D \\
\text { (Range) } \\
\quad(n=12)\end{array}$ & $\begin{array}{l}\mathrm{p}- \\
\text { value* }\end{array}$ \\
\hline $\begin{array}{l}\text { Knowledge and awareness on ethics committee } \\
\text { and function }(n=10)^{\$}\end{array}$ & $\begin{array}{l}81.1 . \pm \\
17.3 \\
(20.0-100)\end{array}$ & $\begin{array}{l}86.9 \pm \\
11.9 \\
(53.0- \\
100)\end{array}$ & $\begin{array}{l}85.3 \pm \\
9.4 \\
(29.4- \\
100)\end{array}$ & $\begin{array}{l}62.5 \pm 23.0 \\
(33.3-100)\end{array}$ & 0.002 \\
\hline Knowledge on ethical principles $(n=4) \$$ & $\begin{array}{l}92.7 \pm \\
15.7 \\
(25.0-100)\end{array}$ & $\begin{array}{l}91.3 \pm \\
14.0 \\
(88.5- \\
92.3)\end{array}$ & $\begin{array}{l}97.1 \pm \\
12.1 \\
(94.1- \\
100)\end{array}$ & $\begin{array}{l}89.6 \pm 22.5 \\
(83.3-100)\end{array}$ & 0.196 \\
\hline Attitude towards ethics committee $(n=9) \$$ & $\begin{array}{l}92.9 \pm 9.9 \\
(66.7-100)\end{array}$ & $\begin{array}{l}93.2 \pm \\
10.9 \\
(84.6- \\
100)\end{array}$ & $\begin{array}{l}94.1 \pm \\
6.9 \\
(82.4- \\
100)\end{array}$ & $\begin{array}{l}90.8 \pm 11.4 \\
(75.0-100)\end{array}$ & 0.705 \\
\hline $\begin{array}{l}\text { Attitude towards research ethical practices }(n=13) \\
\$\end{array}$ & $\begin{array}{l}90.2 \pm \\
10.6 \\
(46.2 .-100)\end{array}$ & $\begin{array}{l}92.3 \pm \\
10.4 \\
(73.1- \\
100)\end{array}$ & $\begin{array}{l}90.5 \pm \\
5.1 \\
(64.7- \\
100)\end{array}$ & $\begin{array}{l}85.3 \pm 15.2 \\
(50.0-100)\end{array}$ & 0.050 \\
\hline Knowledge \& Attitude & $\begin{array}{l}\text { None } \\
\text { Mean } \pm \\
\text { (Range) } \\
(\mathrm{n}=\end{array}$ & & $\begin{array}{l}1-3 \\
\text { Mean } \pm S D \\
\text { (Range) } \\
(n=26)\end{array}$ & $\begin{array}{l}\geq 4 \\
\text { Mean } \pm S D \\
\text { (Range) } \\
\quad(n=19)\end{array}$ & $\begin{array}{l}\text { p- } \\
\text { value* }\end{array}$ \\
\hline $\begin{array}{l}\text { Knowledge and awareness on ERC and research ethics } \\
(n=10)^{\$}\end{array}$ & $\begin{array}{l}70.0 \pm 2 \\
100)\end{array}$ & $8.3(20.0-$ & $\begin{array}{l}81.5 \pm 14.6 \\
100)^{(40.0-}\end{array}$ & $\begin{array}{l}86.1 \pm 17.3 \\
100)^{(60.0-}\end{array}$ & 0.285 \\
\hline Knowledge on ethics and principles $(n=4) \$$ & $\begin{array}{r}85.0 \pm 2 \\
\quad(25 .\end{array}$ & $\begin{array}{l}4.2 \\
-100)\end{array}$ & $\begin{array}{l}94.2 \pm 14.6 \\
100)^{(50.0-}\end{array}$ & $\begin{array}{l}94.7 \pm 10.5 \\
100)^{(75.0-}\end{array}$ & 0.289 \\
\hline Attitude towards ERC and its functions $(n=9) \$$ & $\begin{array}{r}92.2 \pm 1 \\
(66\end{array}$ & $\begin{array}{l}1.8 \\
7-100)\end{array}$ & $\begin{array}{l}91.9 \pm 10.2 \\
100)^{(66.7-}\end{array}$ & $\begin{array}{l}94.7 \pm 8.6 \\
100)^{(77.8-}\end{array}$ & 0.570 \\
\hline Attitude towards ethical and research practice $(n=13)$ & $\begin{array}{r}87.2 \pm 1 \\
(46 .\end{array}$ & 2.0 & $\begin{array}{l}89.1 \pm 10.2 \\
100)^{(61.5-}\end{array}$ & $\begin{array}{l}93.1 \pm 8.1 \\
100)^{(84.6-}\end{array}$ & 0.277 \\
\hline
\end{tabular}

knowledge and awareness of the role of the ethics committee in research, ethical principles in research and views on the 
protocol reviewing approach by the committee were found to be statistically significant. $(p=0.050, p=0.006$, and $p=$ 0.009 respectively).

Table 6 presents the knowledge and awareness of ethics committee and its functions among respondents across different sectors and respondent's involvement in the number of projects. Overall, a significant difference $(p=0.002)$ was noticed across the sectors, and across the number of projects, $(p=0.050)$.

Knowledge of ethical principles: Perceptions of case scenarios allow a detailed study of understanding guidelines and application in a real-life situation. In case scenario number 1, which involves study protocol amendments: $92.7 \%$ of respondents were aware of the process required when an amendment is made on an existing approved study protocol. In case scenario number 2 , which involves children, $90.9 \%$ of respondents were aware of the importance of scenarios where the assent process is mandatory when children are involved in the study. In case scenario number 3 , which involves vulnerable group, $92.7 \%$ of respondents were aware of the necessity of additional safeguards when a vulnerable population is enrolled in studies. In case scenario number 4 , which involves ethical guidelines, only $41.8 \%$ of respondents were aware of the ethical guidelines and codes formulated for human protection. Scenario on guideline was somewhat confusing due to the abbreviations and acronyms used in the questionnaire and the options provided. In case scenario number 5 , which involves functions of the ethics committee, $94.5 \%$ of respondents were aware of the ethics committee's functions. The analysis showed that respondents who handled more than four projects were a strong interpreter for stating familiarity with knowledge on ethical principles $(88.4 \pm 10.1)$ and was found to be statistically significant $(p=0.027)$. No statistically significant difference was observed among respondents across different sectors, although a higher level of understanding (84.7\%) was observed in the research and medical sectors than in the operations sector (75\%) Table 7.

Attitude toward the ethics committee: Table 8 indicates an overall positive attitude toward the ethics committee among the researchers, irrespective of their training status with a mean percentage of ( $92.9 \pm 9.9)$, however, slightly higher percentage was observed $(93.5 \pm 9.5)$ among the respondents who attended ethics training than among those who did not $(90.7 \pm 11.4)$. The overall percentage of attitude toward ethics committee among respondents varied between $85.5 \%$ and $98.2 \%$ with respect to a set of nine questions.

An overall similar optimistic attitude toward ethics committee was observed among respondents across sectors and among respondents who handled different number of projects. The mean over all percentage was found to be (92.9 \pm 9.9$)$ across sectors and among respondents handling different number of projects (Table 9). Respondents encouraged the presence of the ethics committee at the institute and considered their feedback helpful.

Attitude toward ethical research practice: The majority of respondents' attitude toward ethical practices was found to be positive. All the respondents agreed that in a research study, participants should be given the entire details of the study including any risks and benefits, should maintain their confidentiality and privacy and should only be enrolled after obtaining ethical approval. No significant association was found between trained and untrained respondents with their attitude toward research ethical practices Table 10. Results indicate respondents from all sectors were aware of the importance of information given to potential research participants, including complete details of risks versus benefits, obtaining consent before the start of the study; and participant confidentiality (Table 11). Respondents' understanding of concerns on research misconduct, manipulation of data, and overrule of the ethics committee's decision was found to differ significantly $(p=0.024)$ across the sector, and among respondents involved in differing numbers of projects $(p=$ 0.009). These data signify that respondents who handled a greater number of projects exercised and practiced ethical guidelines and attributed high importance to the ethics committee's decision and considered it final.

Table 5: Knowledge and awareness on principles and functions of ERC among respondents attended training on ethics (\% 'correct' responses) 


\begin{tabular}{|c|c|c|c|c|}
\hline Questions & $\begin{array}{c}\text { All } \\
\text { Respondents } \\
(\mathrm{N}=55)\end{array}$ & $\begin{array}{l}\text { Training } \\
\text { Attended } \\
(n=43)\end{array}$ & $\begin{array}{l}\text { Training } \\
\text { Not } \\
\text { attended } \\
(n=12)\end{array}$ & $\begin{array}{l}\mathrm{p}- \\
\text { value }\end{array}$ \\
\hline Do you know when Ethical Review Committee was formed? & 41.8 & 46.5 & 25.0 & 0.182 \\
\hline Do you know ERC at DDI is approved by ministry of health? & 72.7 & 76.7 & 58.3 & 0.205 \\
\hline Do you know members of Ethical Review Committee? & 69.1 & 69.8 & 66.7 & 0.837 \\
\hline Do you know the role of Ethical Review Committee in the research? & 94.5 & 97.7 & 83.3 & 0.050 \\
\hline Are you aware of the ethical principles in research? & 96.4 & 100.0 & 83.3 & 0.006 \\
\hline $\begin{array}{l}\text { Once the protocol or amendments are reviewed in a convened } \\
\text { meeting of ERC or by chairman, do you feel ERC respond in a } \\
\text { reasonable time frame most of the time? }\end{array}$ & 88.2 & 87.5 & 90.9 & 0.756 \\
\hline Any change in the study protocol needs ERC approval & 98.2 & 97.7 & 100.0 & 0.594 \\
\hline How often the ERC meets to review a protocol & 78.2 & 79.1 & 75.0 & 0.763 \\
\hline Have you any time felt that the ERC is biased? & 92.5 & 92.9 & 90.9 & 0.828 \\
\hline $\begin{array}{l}\text { Do you think ERC at DDI reviews research protocol scientifically and } \\
\text { ethically }\end{array}$ & 92.5 & 97.6 & 75.0 & 0.009 \\
\hline Mean \pm SD & $81.1 \pm 17.3$ & $\begin{array}{l}83.3 \\
\pm 14.3\end{array}$ & $73.3 \pm 24.6$ & 0.079 \\
\hline
\end{tabular}

Table 6. Knowledge of ethics committee and functions among respondents across sectors and projects handled (\% 'correct' responses) 


\begin{tabular}{|c|c|c|c|c|c|}
\hline Questions & $\begin{array}{l}\text { Research } \\
\text { (None) }\end{array}$ & $\begin{array}{l}\text { Medical } \\
(1-3)\end{array}$ & $\begin{array}{l}\text { Operations } \\
(\geq 4)\end{array}$ & All & p-value \\
\hline \multirow{3}{*}{$\begin{array}{l}\text { Do you know when Ethical Review Committee was } \\
\text { formed? }\end{array}$} & 53.8 & 29.4 & 33.3 & \multirow{3}{*}{41.8} & 0.226 \\
\hline & & & & & \\
\hline & $(50.0)$ & $(38.5)$ & (42.1) & & $(0.820)$ \\
\hline \multirow{3}{*}{$\begin{array}{l}\text { Do you know ERC at DDI is approved by ministry of } \\
\text { health? }\end{array}$} & 84.6 & 70.6 & 50.0 & \multirow{3}{*}{72.7} & 0.081 \\
\hline & & & & & \\
\hline & $(50.0)$ & $(65.4)$ & (94.7) & & $(0.019)$ \\
\hline \multirow[t]{3}{*}{ Do you know members of Ethical Review Committee? } & 73.1 & 82.4 & 41.7 & \multirow{3}{*}{69.1} & 0.050 \\
\hline & & & & & \\
\hline & $(50.0)$ & $(69.2)$ & $(78.9)$ & & $(0.276)$ \\
\hline \multirow{2}{*}{$\begin{array}{l}\text { Do you know the role of Ethical Review Committee in } \\
\text { the research? }\end{array}$} & 100.0 & 100.0 & 75.0 & \multirow[b]{2}{*}{94.5} & 0.003 \\
\hline & $(80.0)$ & $(96.2)$ & $(100.0)$ & & $(0.070)$ \\
\hline \multirow[t]{2}{*}{ Are you aware of the ethical principles in research? } & 100.0 & 100.0 & 83.3 & \multirow[b]{2}{*}{96.4} & 0.024 \\
\hline & $(80.0)$ & (100.0) & $(100.0)$ & & $(0.009)$ \\
\hline \multirow{3}{*}{$\begin{array}{l}\text { Once the protocol or amendments are reviewed in a } \\
\text { convened meeting of ERC or by chairman, do you feel } \\
\text { ERC respond in a reasonable time frame most of the } \\
\text { time? }\end{array}$} & 88.0 & 100.0 & 66.7 & \multirow{3}{*}{88.2} & 0.043 \\
\hline & & & & & \\
\hline & (87.5) & $(84.0)$ & (94.4) & & $(0.576)$ \\
\hline \multirow[t]{2}{*}{ Any change in the study protocol needs ERC approval } & 100.0 & 100.0 & 91.7 & & 0.161 \\
\hline & $(100.0)$ & $(96.2)$ & $(100.0)$ & 98.2 & $(0.567)$ \\
\hline \multirow[t]{2}{*}{ How often the ERC meets to review a protocol } & 84.6 & 82.4 & 58.3 & & 0.167 \\
\hline & $(80.0)$ & $(76.9)$ & (78.9) & 78.2 & $(0.975)$ \\
\hline \multirow[t]{2}{*}{ Have you any time felt that the ERC is biased? } & 100.0 & 88.2 & 80.0 & & 0.092 \\
\hline & (77.8) & (92.3) & $(100.0)$ & 92.5 & $(0.120)$ \\
\hline \multirow{2}{*}{$\begin{array}{l}\text { Do you think ERC at DDI reviews research protocol } \\
\text { scientifically and ethically }\end{array}$} & 88.5 & 100.0 & 100.0 & & 0.356 \\
\hline & $(87.5)$ & $(100.0)$ & $(84.2)$ & 92.5 & $(0.119)$ \\
\hline \multirow[b]{2}{*}{ Mean \pm SD } & $\begin{array}{l}86.9 \\
\pm 11.9\end{array}$ & $85.3 \pm 9.4$ & $62.5 \pm 23.0$ & \multirow[b]{2}{*}{$81.1 \pm 17.3$} & 0.002 \\
\hline & $70.0 \pm 28.3$ & $81.5 \pm 14.6$ & $86.1 \pm 17.3$ & & $(0.050)$ \\
\hline
\end{tabular}

Figures in $1^{\text {st }}$ rows are for work sectors: Research, Medical \& operation

Figures in $2^{\text {nd }}$ rows ( ) are for Projects involved-in (None, 1-3, $\geq 4$ )

Table 7 Knowledge of ethics principles among respondents across sector and project handled (\% 'Correct' responses) 


\begin{tabular}{|c|c|c|c|c|c|}
\hline Questions & $\begin{array}{l}\text { Research } \\
\text { (None) }\end{array}$ & $\begin{array}{l}\text { Medical } \\
(1-3)\end{array}$ & $\begin{array}{l}\text { Operations } \\
(\geq 4)\end{array}$ & All & $p$-value \\
\hline \multirow[t]{2}{*}{$\begin{array}{l}\text { If you make a substantial amendment to an } \\
\text { approved protocol e.g. an additional objective to the } \\
\text { approved protocol and the inclusion criteria is } \\
\text { changed, when do you think you can start this } \\
\text { change (scenario 18) }\end{array}$} & 92.3 & 100.0 & 83.3 & 92.7 & 0.233 \\
\hline & $(80.0)$ & $(92.3)$ & $(100.0)$ & & $(0.142)$ \\
\hline $\begin{array}{l}\text { Nofel is a } 11 \text {-year-old boy who is attending DDI } \\
\text { pediatric clinic along with his parents. You find him } \\
\text { eligible for your study based on eligibility criteria } \\
\text { fulfillment. His parents signed the consent form and } \\
\text { are keen on him participating in the study. But Nofel } \\
\text { is crying and upset about the prospect of doing an } \\
\text { MRI which is part of the study requirement. Should } \\
\text { Nofel be recruited? (scenario 19) }\end{array}$ & $(90.0)$ & (88.5) & (94.7) & 90.9 & 0.815 \\
\hline \multirow{2}{*}{$\begin{array}{l}\text { A research is being conducted on } 50 \text { pregnant } \\
\text { participants to understand gestational diabetes and } \\
\text { their newborn babies will be followed until } 6 \text { months. } \\
\text { Which of the following best describes this situation? } \\
\text { (scenario 20) }\end{array}$} & 92.3 & 100.0 & 83.3 & & 0.233 \\
\hline & $(700)$ & $(1000)$ & $(017)$ & & () \\
\hline \multirow{3}{*}{$\begin{array}{l}\text { Which of the following is the guidelines followed for } \\
\text { protection of human subjects? (scenario 21) }\end{array}$} & 57.7 & 35.3 & 16.7 & & 0.047 \\
\hline & & & & 41.8 & \\
\hline & $(20.0)$ & $(34.6)$ & $(63.2)$ & & $(0.048)$ \\
\hline \multirow{2}{*}{$\begin{array}{l}\text { Which of the following is the function of } \\
\text { ERC(scenario 22) }\end{array}$} & 92.3 & 94.1 & 100.0 & & 0.622 \\
\hline & $(100.0)$ & $(96.2)$ & (89.5) & 94.5 & $(0.437)$ \\
\hline \multirow{3}{*}{ Mean \pm SD } & $\begin{array}{l}84.6 \\
\pm 15.3\end{array}$ & $84.7 \pm 11.2$ & $75.0 \pm 21.1$ & & 0.179 \\
\hline & & & \multicolumn{3}{|c|}{$82.5 \pm 15.9$} \\
\hline & $72.0 \pm 23.5$ & $82.3 \pm 14.2$ & $88.4 \pm 10.1$ & & $(0.027)$ \\
\hline
\end{tabular}

Figures in $1^{\text {st }}$ rows are for work sectors: Research, Medical \& operations

Figures in $2^{\text {nd }}$ rows ( ) are for Projects involved-in (None, 1-3, $\geq 4$ )

Table 8. Attitude towards ERC among respondents among trained vs untrained (\% 'positive' responses) 


\begin{tabular}{|c|c|c|c|c|}
\hline Questions & $\begin{array}{c}\text { All } \\
\text { Respondents } \\
(\mathrm{N}=55)\end{array}$ & $\begin{array}{l}\text { Training } \\
\text { Attended } \\
(n=43)\end{array}$ & $\begin{array}{l}\text { Training Not } \\
\text { attended } \\
(n=12)\end{array}$ & $\begin{array}{l}\text { p- } \\
\text { value }\end{array}$ \\
\hline \multicolumn{5}{|c|}{ Ethical Review Committee (ERC) is an obstacle to research } \\
\hline & 85.5 & 88.4 & 75.0 & 0.245 \\
\hline \multicolumn{5}{|c|}{ There is no requirement of ERC in the research institute } \\
\hline & 98.2 & 97.7 & 100.0 & 0.594 \\
\hline \multicolumn{5}{|c|}{$\begin{array}{l}\text { Research involving human participants directly or indirectly } \\
\text { must be reviewed by the ERC }\end{array}$} \\
\hline & 98.2 & 97.7 & 100.0 & 0.594 \\
\hline \multicolumn{5}{|c|}{$\begin{array}{l}\text { Clinical trial studies must be reviewed by ERC and approved } \\
\text { before trial initiation }\end{array}$} \\
\hline & 98.2 & 97.7 & 100.0 & 0.594 \\
\hline \multicolumn{5}{|c|}{$\begin{array}{l}\text { ERC review is not required as the research is scientifically } \\
\text { approved }\end{array}$} \\
\hline & 89.1 & 88.4 & 91.7 & 0.746 \\
\hline \multicolumn{5}{|c|}{$\begin{array}{l}\text { Members of the ERC have expertise to review research } \\
\text { ethics }\end{array}$} \\
\hline & 89.1 & 88.4 & 91.7 & 0.746 \\
\hline \multicolumn{5}{|c|}{ Members of the ERC must be trained on ethics periodically } \\
\hline & 96.4 & 97.7 & 91.7 & 0.326 \\
\hline \multicolumn{5}{|c|}{$\begin{array}{l}\text { Concerns or comments of ERC for a reviewed protocol is } \\
\text { according to the ethical principles }\end{array}$} \\
\hline & 92.7 & 93.0 & 91.7 & 0.873 \\
\hline \multicolumn{5}{|c|}{$\begin{array}{l}\text { Feedback received from ERC for a research protocol is } \\
\text { useful }\end{array}$} \\
\hline & 89.1 & 93.0 & 75.0 & 0.077 \\
\hline Mean \pm SD & $92.9 \pm 9.9$ & $93.5 \pm 9.5$ & $90.7 \pm 11.4$ & 0.391 \\
\hline
\end{tabular}

Table 9. Attitude towards ERC among respondents across sectors and projects handled (\% 'positive' responses) 


\begin{tabular}{|c|c|c|c|c|c|}
\hline Questions & $\begin{array}{l}\text { Research } \\
\text { (None) }\end{array}$ & $\begin{array}{l}\text { Medical } \\
(1-3)\end{array}$ & $\begin{array}{l}\text { Operations } \\
(\geq 4)\end{array}$ & All & p-value \\
\hline \multirow[t]{2}{*}{ Ethical Review Committee (ERC) is an obstacle to research } & 84.6 & 94.1 & 75.0 & & 0.351 \\
\hline & $(80.0)$ & $(76.9)$ & $(100.0)$ & 85.5 & $(0.082)$ \\
\hline \multirow[t]{2}{*}{ There is no requirement of ERC in the research institute } & 100.0 & 100.0 & 91.7 & & 0.161 \\
\hline & $(90.0)$ & $(100.0)$ & $(100.0)$ & 98.2 & $(0.101)$ \\
\hline \multirow{2}{*}{$\begin{array}{l}\text { Research involving human participants directly or indirectly } \\
\text { must be reviewed by the ERC }\end{array}$} & 96.2 & 100.0 & 100.0 & & 0.567 \\
\hline & $(100.0)$ & $(96.2)$ & $(100.0)$ & 98.2 & $(0.567)$ \\
\hline \multirow{2}{*}{$\begin{array}{l}\text { Clinical trial studies must be reviewed by ERC and approved } \\
\text { before trial initiation }\end{array}$} & 100.0 & 94.2 & 100.0 & & 0.320 \\
\hline & $(100.0)$ & $(96.2)$ & $(100.0)$ & 98.2 & $(0.567)$ \\
\hline \multirow{2}{*}{$\begin{array}{l}\text { ERC review is not required as the research is scientifically } \\
\text { approved }\end{array}$} & 84.6 & 94.1 & 91.7 & & 0.589 \\
\hline & $(90.0)$ & $(88.5)$ & $(89.5)$ & 89.1 & $(0.989)$ \\
\hline \multirow[t]{2}{*}{ Members of the ERC have expertise to review research ethics } & 88.5 & 88.2 & 91.7 & & 0.949 \\
\hline & $(100.0)$ & $(88.5)$ & $(84.2)$ & 89.1 & $(0.427)$ \\
\hline \multirow[t]{2}{*}{ Members of the ERC must be trained on ethics periodically } & 96.2 & 100.0 & 91.7 & & 0.497 \\
\hline & $(90.0)$ & $(96.2)$ & $(100.0)$ & 96.4 & $(0.391)$ \\
\hline \multirow{2}{*}{$\begin{array}{l}\text { Concerns or comments of ERC for a reviewed protocol is } \\
\text { according to the ethical principles }\end{array}$} & 96.2 & 94.1 & 83.3 & & 0.355 \\
\hline & $(90.0)$ & $(96.2)$ & $(100.0)$ & 92.7 & $(0.650)$ \\
\hline \multirow[t]{2}{*}{ Feedback received from ERC for a research protocol is useful } & 92.3 & 82.4 & 91.7 & & 0.562 \\
\hline & $(90.0)$ & $(88.5)$ & $(89.1)$ & 89.1 & $(0.989)$ \\
\hline \multirow[t]{2}{*}{ Mean \pm SD } & $\begin{array}{l}93.2 \pm \\
10.9\end{array}$ & $\begin{array}{l}94.1 \pm \\
6.9\end{array}$ & & $\begin{array}{l}92.9 \\
\pm\end{array}$ & 0.662 \\
\hline & $\begin{array}{l}92.2 \pm \\
11.8\end{array}$ & $\begin{array}{l}91.9 \pm \\
10.2\end{array}$ & \pm 8.6 & $\begin{array}{l}9.9 \\
92.9 \\
\pm \\
9.9\end{array}$ & $(0.621)$ \\
\hline
\end{tabular}

Figures in $1^{\text {st }}$ rows are for work sectors: Research, Medical \& operations

Figures in $2^{\text {nd }}$ rows ( ) are for Projects involved-in (None, 1-3, $\geq 4$ )

Table 10: Attitude toward ethical research practices among trained vs non trained (\% 'positive' responses) 


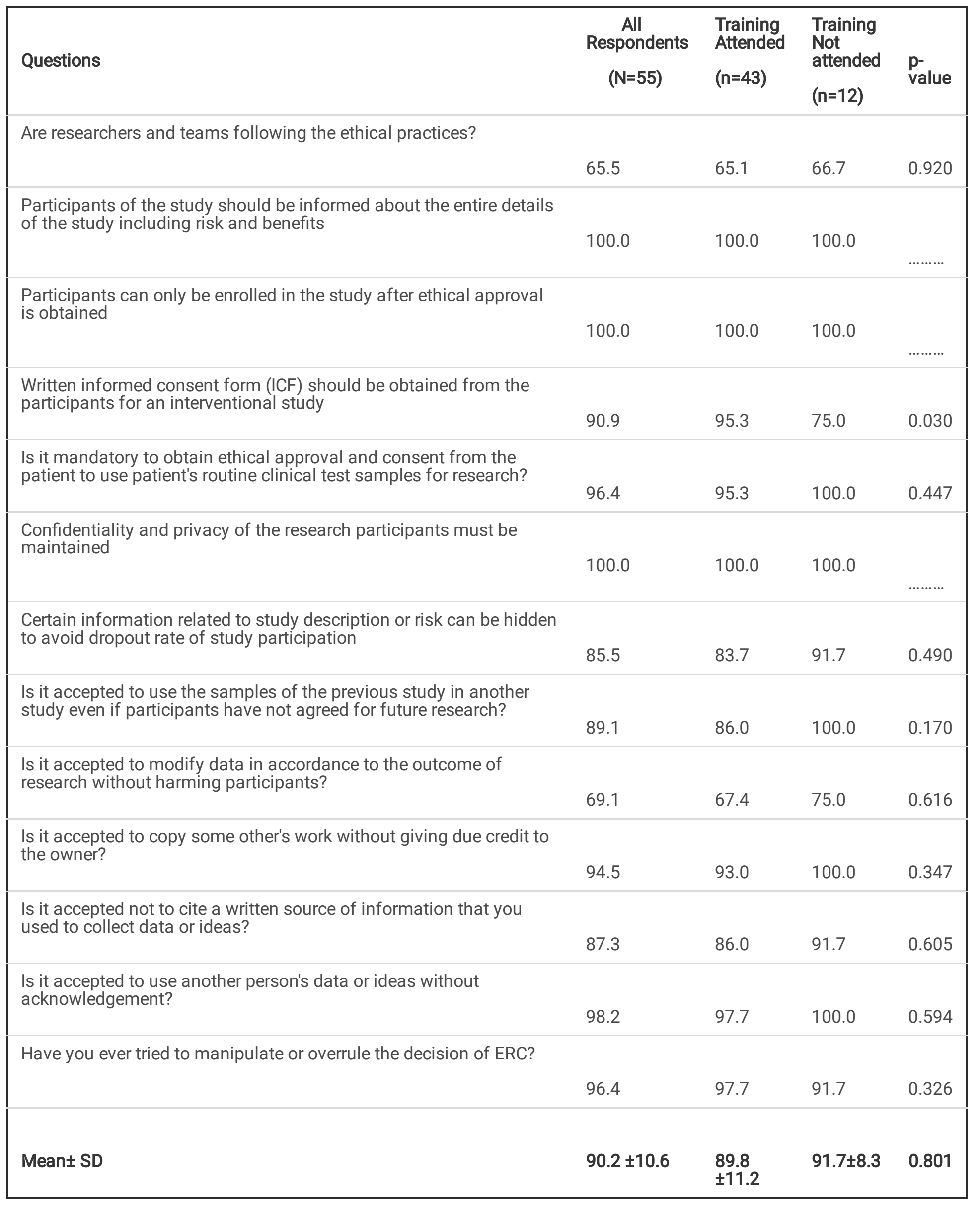


Table 11: Attitude toward ethical research practices across sectors and number of projects involved in (\% 'positive' responses)

\begin{tabular}{|c|c|c|c|c|c|}
\hline Questions & $\begin{array}{l}\text { Research } \\
\text { (None) }\end{array}$ & $\begin{array}{l}\text { Medical } \\
(1-3)\end{array}$ & $\begin{array}{l}\text { Operations } \\
\qquad(\geq 4)\end{array}$ & All & p-value \\
\hline \multirow{2}{*}{$\begin{array}{l}\text { Are researchers and teams following the ethical } \\
\text { practices? }\end{array}$} & 73.1 & 64.7 & 50.0 & & 0.379 \\
\hline & $(60.0)$ & (69.2) & (63.2) & 65.5 & $(0.844)$ \\
\hline \multirow{2}{*}{$\begin{array}{l}\text { Participants of the study should be informed about } \\
\text { the entire details of the study including risk and } \\
\text { benefits }\end{array}$} & 100.0 & 100.0 & 100.0 & & - \\
\hline & 100.0 & 100.0 & 100.0 & 100.0 & - \\
\hline \multirow{2}{*}{$\begin{array}{l}\text { Participants can only be enrolled in the study after } \\
\text { ethical approval is obtained }\end{array}$} & 100.0 & 100.0 & 100.0 & & - \\
\hline & 100.0 & 100.0 & 100.0 & 100.0 & - \\
\hline \multirow{2}{*}{$\begin{array}{l}\text { Written informed consent form (ICF) should be } \\
\text { obtained from the participants for an interventional } \\
\text { study }\end{array}$} & 88.5 & 94.1 & 91.7 & & 0.815 \\
\hline & $(80.0)$ & $(100.0)$ & (84.2) & 90.9 & $(0.079)$ \\
\hline \multirow{2}{*}{$\begin{array}{l}\text { Is it mandatory to obtain ethical approval and } \\
\text { consent from the patient to use patient's routine } \\
\text { clinical test samples for research? }\end{array}$} & 96.2 & 94.1 & 100.0 & & 0.704 \\
\hline & (100.0) & $(96.2)$ & $(94.7)$ & 96.4 & (0.769) \\
\hline \multirow{2}{*}{$\begin{array}{l}\text { Confidentiality and privacy of the research } \\
\text { participants must be maintained }\end{array}$} & 100.0 & 100.0 & 100.0 & & - \\
\hline & (100.0) & (100.0) & (100.0) & 100.0 & - \\
\hline \multirow{2}{*}{$\begin{array}{l}\text { Certain information related to study description or } \\
\text { risk can be hidden to avoid dropout rate of study } \\
\text { participation }\end{array}$} & 88.5 & 82.4 & 83.3 & & 0.834 \\
\hline & $(90.0)$ & (76.9) & $(94.7)$ & 85.5 & $(0.222)$ \\
\hline \multirow{2}{*}{$\begin{array}{l}\text { Is it accepted to use the samples of the previous } \\
\text { study in another study even if participants have not } \\
\text { agreed for future research? }\end{array}$} & 88.5 & 94.1 & 83.3 & & 0.650 \\
\hline & $(90.0)$ & $(84.6)$ & $(94.7)$ & 89.1 & $(0.558)$ \\
\hline \multirow{2}{*}{$\begin{array}{l}\text { Is it accepted to modify data in accordance to the } \\
\text { outcome of research without harming participants? }\end{array}$} & 73.1 & 70.6 & 58.3 & & 0.650 \\
\hline & $(70.0)$ & $(61.5)$ & (78.9) & 69.1 & $(0.458)$ \\
\hline \multirow{2}{*}{$\begin{array}{l}\text { Is it accepted to copy some other's work without } \\
\text { giving due credit to the owner? }\end{array}$} & 96.2 & 100.0 & 83.3 & & 0.133 \\
\hline & $(90.0)$ & (92.3) & (100.0) & 94.5 & $(0.417)$ \\
\hline \multirow{2}{*}{$\begin{array}{l}\text { Is it accepted not to cite a written source of } \\
\text { information that you used to collect data or ideas? }\end{array}$} & 96.2 & 76.5 & 83.3 & & 0.150 \\
\hline & $(90.0)$ & (76.9) & (100.0) & 87.3 & $(0.069)$ \\
\hline \multirow{2}{*}{$\begin{array}{l}\text { Is it accepted to use another person's data or ideas } \\
\text { without acknowledgement? }\end{array}$} & 100.0 & 100.0 & 91.7 & & 0.161 \\
\hline & $(90.0)$ & $(100.0)$ & $(100.0)$ & 98.2 & $(0.101)$ \\
\hline \multirow{3}{*}{$\begin{array}{l}\text { Have you ever tried to manipulate or overrule the } \\
\text { decision of ERC? }\end{array}$} & 100.0 & 100.0 & 83.3 & & 0.024 \\
\hline & $(80.0)$ & $(100.0)$ & (100.0) & 96.4 & $(0.009)$ \\
\hline & $92.3 \pm 10.4$ & $90.5 \pm 5.1$ & $85.3 \pm 15.2$ & $90.2 \pm 10.6$ & 0.163 \\
\hline Mean \pm SD & $87.7 \pm 15.0$ & $89.1 \pm 10.2$ & $93.1 \pm 8.1$ & $90.2 \pm 10.6$ & $(0.323)$ \\
\hline
\end{tabular}

Figures in $1^{\text {st }}$ rows are for work sectors: Research, Medical \& operations

Figures in $2^{\text {nd }}$ rows ( ) are for Projects involved-in (None, 1-3, $\geq 4$ ) 


\section{Discussion}

Our survey study provides discernment of the knowledge, awareness, and attitudes of researchers across the three different sectors of DDI, namely research, medical and operations.

DDI has highly experienced researchers with a mean age of 42.8 years and a mean year of experience of 16.8 years. Knowledge and awareness of ethics committee and its function among respondents from the three sectors varied significantly with research sector at $87 \%$, medical sector at $85 \%$ and operations at $63 \%$. The low percentage of awareness among operations sector reflects that the respondents from the operations sector were not directly involved in human subject research activities. The physicians awareness in the medical sector in this survey is in accordance with the Demour et al. study at Jordan indicating $86.8 \%$ of physicians were aware of the role of ethics committee [21]. Contrasting results were reported in Lebanon based research in which only $62.5 \%$ of physicians knew about ethics committee [20]. By and large in our survey, research and medical sectors scored maximum correct responses in comparison to operations sector toward the questions on knowledge and awareness on role of ethics committee, ethical principles and its functions.

Significant association was observed between number of projects handled and ethics training among respondents in our survey. This is in accordance with Lebanon paper which indicates significant higher knowledge among physicians with prior research experience and those who had prior ethics training [20]. The percentage of trained respondents was found to be $78.2 \%$ in our survey whereas, other studies reported percentage of ethics trained respondents ranging from nil to $36.8 \%$ to $53.7 \%$ to $64 \%$.[18-21]. Interestingly in our survey, overall, no association was found between training and knowledge on ethics committee and its function. However, significant association was found on questions related to role of ethics committee, ethical principles and the review process of ethics committee.

In our survey, $94.5 \%$ of respondents were aware of the role of the ethics committee. This can be compared with other published papers, in which the percentage ranged from $8.8 \%$ to $40 \%$ of respondents $[21,20]$. Most studies from the Middle East have demonstrated a need for better knowledge of and improved attitudes toward research ethics, with prior ethics training an independent predictor for the extent of respondents' knowledge of research ethics [18-20]. The response rate of $86.6 \%$ in our survey reflects the participation of a majority of researchers as compared with other studies that reported between $51 \%$ and $62.5 \%$ response rates $[18,19]$.

In our survey, among the trained respondents, $97.7 \%$ were aware of the role and functions of the ethics committee, similar results were reported in Jordan and India [21, 22]. By contrast, a study from Jordan by Tarboush et al. reported that the role of the ethics committee was not well understood by most of their study participants [19]. Prior ethics training and years of experience had direct linear relationship with the number of research projects being handled in our survey. In the present study, $92.5 \%$ of researchers were of the positive opinion that justice has been done during protocol reviews and approvals, whereas $31 \%$ of respondents in one of the study reported delay in response from the ethics committee [21]. According to our results generated from case scenarios, respondents rightly perceived their responsibility when implementing ethics in research projects. The emphasis was to preserve the integrity of research and to protect the welfare of human participants enrolled in the research studies. Similar to other reported studies, a large majority (92.7\%) of our respondents across sectors were aware of the elements of informed consent form such as respect, beneficence, confidentiality, and protections to vulnerable populations [21, 22].

Research on human subjects is constantly increasing in the Middle East and the North Africa region, making persistent monitoring of studies mandatory. Misconduct and fabrication of data persist in the scientific world even today [23]. Research may lead to harmful effects on participants or other associated parties when conducted unethically [24]. Because of this, we wanted to assess DDI's researchers' attitude toward ethics practices including their opinions on fabrication, concealing information from participants to prevent them from dropping out and plagiarism. Over $90 \%$ of

Page $17 / 21$ 
respondents from across sectors showed negativity toward unlawful ethical practices and supported researchers providing credit to authors whenever they adopted their ideas and knowledge. Over $90 \%$ of the respondents across the sectors were aware of the conflict of interest and other ethical considerations taken into account when publishing a research article.

DDI is a small institute with intensive research only on diabetes, so the number of respondents was relatively small in this survey which was conducted only at one institute in Kuwait. The survey questionnaires were adopted from published articles but were not validated. Moreover, the details regarding the type of courses and workshops that the researchers had attended were not documented.

\section{Conclusion}

Aim of this survey was to assess the awareness of ethics committee, its function and attitude toward ethics committee and research ethical practices among the researchers across the three sectors. Responses obtained were analyzed to find out if there are any differences or association in the ethical awareness and attitude among the respondents with respect to their sectors and number of projects handled. We found that the respondents' knowledge on ethics committee varied significantly and attitude toward ethical research practices varied with marginal significance across sectors. Whereas, no significance was found on the knowledge of ethics committee and attitude toward ethical research practices across different number of projects handled by the respondents. This indicate gap in the awareness among researchers even though they belong to the same institute and follow same policies of governance. Customized and continuous ethics training based on the type of research can bridge this gap.

\section{Abbreviations}

DDI- Dasman Diabetes Institute

SPSS- Statistical Package for Social Sciences

SD- Standard Deviation

IQ- Interquartile

\section{Declarations}

\section{Ethics approval and consent to participate}

Ethical clearance was obtained from DDl's Ethics Review Committee. The study was assigned number RA HM-2019-029. All data were collected anonymously, and all information was kept confidential. No names or other identifiers were requested from the participants to be included in the questionnaire. All questionnaires were filled electronically and collected only after participants gave their implied consent by clicking on the continue button in the online questionnaire.

\section{Consent for publication}

Not applicable.

\section{Availability of data and materials}

All data sets used or analyzed during the current study are available from the corresponding author on reasonable request.

\section{Competing interests}

The authors declare no conflict of interest or financial interests. 
This research was supported by minimal funding from DDI, a subsidiary of the Kuwait Foundation for the Advancement of Sciences, a nonprofit, nongovernmental center. The funders had no role in study design, data collection and analysis, decision to publish, or preparation of the manuscript.

\section{Authors' contributions}

RS conceived the idea; designed, analyzed, and interpreted data; and revised the draft manuscript. ST contributed to designing the questionnaire and writing the draft manuscript. AA contributed to designing the questionnaire and revising the manuscript. PS conducted statistical analysis, and interpretation of data and reviewed the manuscript. AB was involved in study design and critically reviewed and revised the manuscript. All authors read and approved the final manuscript.

\section{Acknowledgements}

We would like to thank the DDI researchers for taking the time to fill out the online survey forms

\section{References}

1. Ostman L, Nasman Y, Eriksson K, Nystrom L. Ethos: The heart of ethics and health. Nurs Ethics. 2019;26(1):26-36. doi:10.1177/0969733017695655.

2. Haddad LM, Geiger RA. Nursing Ethical Considerations. In: StatPearls\{internet\}. StatPearls publishing, Treasure Island (FL). 2021. https://www.ncbi.nlm.nih.gov/pubmed/30252310. Accessed 19 January 2021.

3. NIoEH SN. What is Ethics in Research \& Why Is It Important? https://www.niehs.nih.gov/research/resources/bioethics/whatis/index.cfm. Accessed 23 December 2020.

4. CIOMS. International Ethical Guidelines for Biomedical Research Involving Human Subjects. Geneva, Switzerland. 2002. https://cioms.ch/wpcontent/uploads/2016/08/International_Ethical_Guidelines_for_Biomedical_Research_Involving_Human_Subjects.pdf. Accessed 20 December 2020.

5. Das NK, Sil A. Evolution of Ethics in Clinical Research and Ethics Committee. Indian J Dermatol. 2017;62(4):373-9. doi:10.4103/ijd.IJD_271_17.

6. Lasker S. History of clinical research and ethics. BJBio. 2013;1(4).

7. NIH. Research Ethics Timeline. https://www.niehs.nih.gov/research/resources/bioethics/timeline/index.cfm. Accessed 04 January 2020.

8. Rice TW. The historical, ethical, and legal background of human-subjects research. Respir Care. 2008;53(10):1325-9.

9. Debnath J. Plagiarism: A silent epidemic in scientific writing - Reasons, recognition and remedies. Med J Armed Forces India. 2016;72(2):164-7. doi:10.1016/j.mjafi.2016.03.010.

10. HHS. Ethical Principles and Guidelines for the Protection of Human Subjects of Research. https://www.hhs.gov/ohrp/sites/default/files/the-belmont-report-508c_FINAL.pdf. Accessed 21 December 2020.

11. C. Brown;J.Spiro SQ. The role of research ethics committees: Friend or Foe in educational research? An exploratory study. BrEducResJ. 2020;46(4). doi:DOI:10.1002/berj.3654.

12. Ibingira BR, Ochieng J. Knowledge about the research and ethics committee at Makerere University, Kampala. Afr Health Sci. 2013;13(4):1041-6. doi:10.4314/ahs.v13i4.26.

13. Li JR, Walker S, Nie JB, Zhang XQ. Experiments that led to the first gene-edited babies: the ethical failings and the urgent need for better governance. J Zhejiang Univ Sci B. 2019;20(1):32-8. doi:10.1631/jzus.B1800624. 
14. George SL, Buyse M. Data fraud in clinical trials. Clin Investig (Lond). 2015;5(2):161-73. doi:10.4155/cli.14.116.

15. Boetto E, Golinelli D, Carullo G, Fantini MP. Frauds in scientific research and how to possibly overcome them. J Med Ethics. 2020. doi:10.1136/medethics-2020-106639.

16. Felaefel M, Salem M, Jaafar R, Jassim G, Edwards H, Rashid-Doubell F et al. A Cross-Sectional Survey Study to Assess Prevalence and Attitudes Regarding Research Misconduct among Investigators in the Middle East. J Acad Ethics. 2018;16(1):71-87. doi:10.1007/s10805-017-9295-9.

17. Grady C. Institutional Review Boards: Purpose and Challenges. Chest. 2015;148(5):1148-55. doi:10.1378/chest.150706.

18. El-Dessouky HF, Abdel-Aziz AM, Ibrahim C, Moni M, Abul Fadl R, Silverman H. Knowledge, Awareness, and Attitudes about Research Ethics among Dental Faculty in the Middle East: A Pilot Study. Int J Dent. 2011;2011:694759. doi:10.1155/2011/694759.

19. Tarboush NA, Alkayed Z, Alzoubi KH, Al-Delaimy WK. The understanding of research ethics at health sciences schools in Jordan: a cross-sectional study. BMC Med Educ. 2020;20(1):121. doi:10.1186/s12909-020-02040-5.

20. Azakir B, Mobarak H, Al Najjar S, El Naga AA, Mashaal N. Knowledge and attitudes of physicians toward research ethics and scientific misconduct in Lebanon. BMC Med Ethics. 2020;21(1):39. doi:10.1186/s12910-020-00475-5.

21. Al Demour S, Alzoubi KH, Alabsi A, Al Abdallat S, Alzayed A. Knowledge, awareness, and attitudes about research ethics committees and informed consent among resident doctors. Int J Gen Med. 2019;12:141-5. doi:10.2147/IJGM.S197511.

22. Munoli S NG, Deepthi R. Knowledge, attitude and practice of research ethics among medical faculty in a teaching hospital. Int J Basic Clin Pharmacol. 2017;6(4):6. doi:DOI: 10.18203/2319 - 2003.ijbcp20171103.

23. Stavale R, Ferreira GI, Galvao JAM, Zicker F, Novaes M, Oliveira CM et al. Research misconduct in health and life sciences research: A systematic review of retracted literature from Brazilian institutions. PLoS One.

2019;14(4):e0214272. doi:10.1371/journal.pone.0214272.

24. Sanjari M, Bahramnezhad F, Fomani FK, Shoghi M, Cheraghi MA. Ethical challenges of researchers in qualitative studies: the necessity to develop a specific guideline. J Med Ethics Hist Med. 2014;7:14.

\section{Figures}




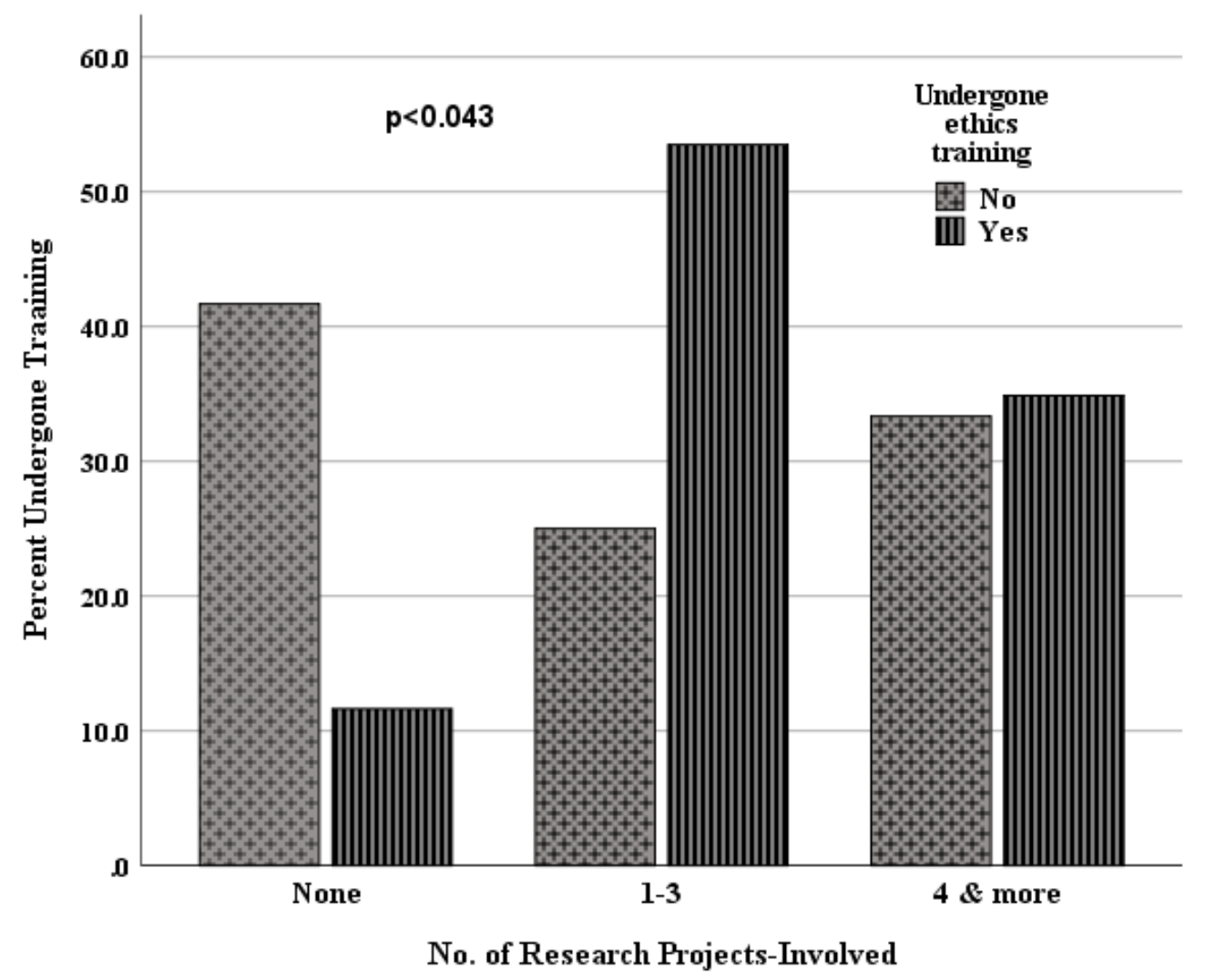

Figure 1

Researchers' involvement according to number of projects and ethics training attended.

\section{Supplementary Files}

This is a list of supplementary files associated with this preprint. Click to download.

- Additionalfile1Questionnaire.docx 